\title{
Physical Sources of Biblical History
}

\author{
Jetze Touber
}

\section{OpenEdition}

\section{Journals}

\section{Electronic version}

URL: http://journals.openedition.org/hms/1085

DOI: $10.4000 / \mathrm{hms} .1085$

ISSN: 2557-2113

\section{Publisher}

Presses universitaires du Midi

\section{Printed version}

Date of publication: 15 July 2017

Number of pages: $35-54$

ISBN: 978-2-8107-0527-6

ISSN: 2263-8911

Brought to you by Ghent University Library

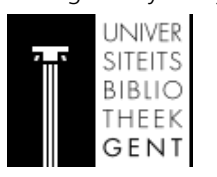

Electronic reference

Jetze Touber, «Physical Sources of Biblical History », Histoire, médecine et santé [Online], 11 | été 2017. Online since 20 October 2017, connection on 28 September 2020. URL : http:// journals.openedition.org/hms/1085; DOI : https://doi.org/10.4000/hms.1085

\section{(c) (i) (9)}

Histoire, médecine et santé est mise à disposition selon les termes de la Licence Creative Commons Attribution - Pas d'Utilisation Commerciale - Pas de Modification 4.0 International. 


\title{
Physical Sources of Biblical History
}

\author{
Jetze Touber \\ Ghent University
}

The Reformation and the consequent divergence of religious cultures in Europe had profound consequences for intellectual regimes across the continent. Learned medicine was no exception in that respect. One area where we may gauge the effects of this development was in the field of medicina sacra: the application of medical knowledge to the interpretation of biblical passages touching upon the workings of the human body. The engagement of learned medicine with Scripture may be expected to have been differentiated confessionally, seeing the very different position of the Bible had in Catholic and Protestant cultures. This particular branch of physica sacra has hardly been studied, however. The present article probes a very modest sample of medical knowledge brought to bear on biblical interpretation, by the Catholic authors Francisco Valles and Girolamo Bardi, and by the Protestant authors Johannes Mey and Thomas Bartholin. This will serve to open up discussion as to the actual confessional divarication in early modern medicina sacra.

Keywords: medicina sacra, learned medicine, biblical interpretation, theology

La Réforme et la divergence des cultures religieuses en Europe qui en résulta eurent des conséquences profondes sur les régimes intellectuels dans tout le continent. La médecine savante n'a pas été une exception à cet égard. Un terrain où nous pouvons examiner les effets de ce phénomène est celui de la medicina sacra, à savoir l'usage du savoir médical dans l'interprétation des passages bibliques qui concernent les fonctions du corps humain. On peut s'attendre à ce que l'engagement de la médecine savante au sujet de l'Écriture ait été hétérogène selon les confessions, étant donné la place très différente de la Bible dans les cultures catholique et protestante. Or cette branche spécifique de la physica sacra a été très peu étudiée. Cet article explore un échantillon réduit de textes médicaux aux prises avec l'interprétation biblique - ceux des auteurs catholiques Francisco Valles et Girolamo Bardi, et ceux des protestants Johannes Mey et Thomas Bartholin. Il se veut ainsi une contribution à la discussion sur les clivages confessionnels de la medicina sacra à l'Époque moderne.

Mots-clés : medicina sacra, médecine savante, interprétation biblique, théologie

I would like to express my gratitude to the editors of this special issue for inviting me to contribute with an article, to José Pardo-Tomás for providing invaluable information, as well as to the two anonymous referees for their insightful comments. All shortcomings are my sole responsibility.

Jetze Touber, « Physical Sources of Biblical History », Histoire, médecine et santé, II, été 20I7, p. 35-54. 
In 1588 Cesare Baronio (I538-I607), famous church historian, enlisted the assistance of the papal physician Michele Mercati (I54I-I593) to clarify a passage in the Gospels. As Jesus Christ ascends Mount Calvary, someone offers him wine mixed with a certain substance. According to Matthew the wine contained "gall"; Marc mentioned wine treated with "myrrh". The Evangelists agreed that Christ refused to drink the mixture. 'The passage invited speculation on whether the wine had a palliative effect, or was conversely meant to exacerbate Christ's torment.

In the first volume (I588) of the Annales Ecclesiastici, Baronio's monumental church history, the author had to deal with these passages. True to his indiscriminate use of sources, textual, visual and material, he drew upon a recent experience to substantiate his claim that Christ had done exactly as expected. Baronio received a specimen of an exotic resin from his friend, the papal physician Michele Mercati. This Tuscan scholar had collected minerals at the Vatican since his arrival in Rome. His extensive collection included an amount of "myrrh" originating overseas. Tasting the myrrh, Baronio and Mercati noted that it had a wonderfully sweet effect. This proved that in refusing the vinum myrrhatum, in effect Christ had turned down an alleviation of his pain, thus embracing in full the torment that constituted his sacrifice for humanity. ${ }^{2}$ The experiential knowledge provided by a physician fitted in seamlessly with the many documents and antiquities that Baronio incorporated in his historical construction. ${ }^{3}$

The church historian, in other words, appealed to knowledge pertaining to natural history, generated by a scholar versed in medicine, so as to buttress his claim concerning the passion of Christ. ${ }^{4}$ Baronio's appeal to the medical doctor Mercati is no isolated instance. Repeatedly learned medicine came to the aid of biblical interpretation. We may think of Melchior Wieland (I520-I589), botanist at Padua, praised by the theologian Girolamo Vielmi (ca. I5I9-I582) in the latter's hexameron, for assisting him with understanding Genesis I:II. In that verse, God commands the earth to bring forth "seed bearing plants". ${ }^{5}$ Vielmi stumbled upon Theophrastus who claimed that all plants bear seed, making the qualification "seed bearing" redundant. Vielmi was, however, reassured by talking with Wieland that the phrase was not meaningless. There were also plants that were

\footnotetext{
I | Matthew 27:34; Marc I5:23.

2 | I have used Cesare Baronio, Annales ecclesiastici, I, Rome, Donangeli, I59I, p. 204.

3 Stefano Zen, Baronio storico. Controriforma e crisi del metodo umanistico, Naples, Vivarium, I994, p. $8 \mathrm{I}-82$.

4| Harold Cook, "Physicians and Natural History", in Nicholas Jardine and James Secord (ed.), Cultures of Natural History, Cambridge, Cambridge University Press, 1996, p. 9I-IO5.

$5 \mid$ herbam virentem et facientem semen, Genesis I:II.
} 
"sterile". ${ }^{6}$ Again, Ulisse Aldrovandi (I522-I605) was repeatedly admonished by members of the Paleotti family in Bologna to apply his biological expertise to explain obscure biblical references to nature. ${ }^{7}$ These are Catholic examples of an appeal to worldly knowledge in biblical exegesis, often associated rather with the Protestant world. Well-known are early modern Protestant zoologia sacra, the study of animals occurring in the Bible, and geographia sacra, the investigation of territories covered in the Bible. ${ }^{8}$ As we will see, we may add medicina sacra to this list, in the Protestant world as well.

This essay is a first attempt to understand the ways in which medicine and natural history interacted with biblical scholarship, in Protestant and Catholic confessional contexts, respectively. I will do so by probing a small sample of writings in which medical expertise was brought to bear fully on sacred history. I subsume these writings under the heading of medicina sacra. The works examined, two written by Catholic authors, two by Protestant authors, have different structures and were written in different contexts. However, they have in common that their author was steeped in medical knowledge, which informed a good deal of their engagement with the sacred text of the Bible.

First, we consider very briefly and in general terms the relationship in this period between theology and biblical hermeneutics, on the one hand, and medicine, natural history and natural philosophy, on the other. Then we will examine some instances of medicina sacra, an early modern nexus of theology and medicine. The paper ends with a suggestion how more thorough research along these lines could produce a more refined understanding of the mutual relationship of learned medicine and theology, in a transconfessional perspective, between I550 and I700.

6| Melchior Guilandinus [...] admonuit, Auctores inter steriles enuumerare (sic) Epimedium, Polipodium, utranque filicem, fungos, \& alias quasdam. Girolamo Vielmi, De sex diebus conditi orbis liber, Venice, Giunta, 1575, p. 335; see Andrew D. Berns, The Bible and Natural Philosophy in Renaissance Italy: Jewish and Christian Physicians in Search of Truth, New York, Cambridge University Press, 2015, p. 7, 75-77.

$7 \mid$ Berns, The Bible and Natural Philosophy..., op. cit., p. 37-39.

8| Luc Daireaux, "Au service de l'érudition : Samuel Bochart et les Provinces-Unies (I599-1667)", in Yves Krumenacker (ed.), Entre calvinistes et catholiques : les relations religieuses entre la France et les Pays-Bas du Nord (XVI ${ }^{e}$-XVIII ${ }^{e}$ siècle), Rennes, Presses universitaires de Rennes, 20IO, p. 223-238; Zur Shalev, "Early Modern Geographia Sacra in the Context of Early Modern Scholarship", in Kevin Killeen et al. (ed.), The Oxford Handbook of the Bible in Early Modern England, C. I530-I70o, Oxford, Oxford University Press, 2015, p. 195-208. 


\section{Theology and learned medicine}

"The Lord hath created medicines out of the earth; and he that is wise will not abhor them." This verse from the Book of Sirach provided biblical credentials for the practitioners of the medical arts. Even if Protestants considered this book of the Bible apocryphical, they cited the verse freely to convey God's endorsement of the medical profession, no less than Catholics. ${ }^{10}$ Since the Patristic age, matters of health and healing occurring in the Bible ensured that theology and the medical arts had a common interest. ${ }^{\text {II }}$ After Latin Christianity split up in various denominations after 1500 , systematic theology as well as pastoral practice branched out in markedly different directions. This had implications for the relationship between theology and learned medicine in the respective cultural areas.

To some extent, our historiography concerning the relationship between theology and learned medicine in the early modern age is still conditioned by a grand narrative that regards the Reformation as the breeding ground for the transformation of the study of nature between 1550 and I700. In this view Protestants distinguished themselves from Catholics by their critical attitude and interest in empirical observation. This has caused the assumption to take root that Catholic science, including medicine, was backwards-looking and eschewed novelties, whereas Protestant science was innovative and modern. ${ }^{12}$

$9 \mid$ Sirach 38:4.

Io| Sandra Pott, Säkularisierung in den Wissenschaften seit der Frühen Neuzeit I Medizin, Medizinethik und schöne Literatur: Studien zu Säkularisierungsvorgängen vom frühen I7. bis zum frühen 19. Jahrhundert, Berlin, De Gruyter, 2002, p. 80; Gary B. Ferngren, Medicine and Religion: A Historical Introduction, Baltimore, Johns Hopkins University Press, 2014, p. I43; Guido Giglioni, Immaginazione e malattia: saggio su Jan Baptiste van Helmont, Milan, FrancoAngeli, 2000, p. 22.

II | Darrel W. Amundsen and Gary B. Ferngren, "Medicine and Religion: Early Christianity Through the Middle Ages", in Martin E. Marty and Kenneth L. Vaux (ed.), Health/Medicine and the Faith Traditions, Philadelphia, Fortress Press, I982, p. 93-I3I (93-II2); Gregor Etzenmüller and Annette Weissenrieder, "Christentum und Medizin. Welche Kopplungen sind lebensförderlich?", in Gregor Etzelmüller and Annette Weissenrieder (ed.), Religion und Krankheit, Darmstadt, WBG, 2012, p. II-32 (15-17).

I2 | As summarized succinctly by Antonella Romano: "le thème "science et religion" a principalement trouvé à se déployer autour du double éclatement de la chrétienté entre catholiques et protestants et de la construction des savoirs entre tradition et modernité." Antonella Romano, "La science moderne, ses enjeux, ses pratiques et ses résultats en contexte catholique", in A. Romano (ed.), Rome et la science moderne, Rome, École française de Rome, 2008, p. 3-44 (I7). See the recent work on the relation between medicine and religion in the Catholic world by Maria Pia Donato, who avoids such a schematization: Maria Pia Donato, Morti improvvise: medicina e religione nel Settecento, Roma, Carocci, 20IO; ead et al. (ed.), Médecine et religion : compétitions, collaborations, conflits ( $\mathrm{XII}^{e}-\mathrm{xx}^{e}$ siècles), Rome, École française de Rome, 20I3, with an excellent historiographical introductory essay on p. 9-33. 
The force of this assumption may be illustrated by the contradictory meanings attached to a similar tendency among Protestants and Catholics. In distinct publications, both English Puritans and German Lutherans of the Seventeenth Century have been shown to have favoured collecting experimental findings over constructing conceptual systems. Both groups have been praised for this reason as exponents of Baconian induction, which laid a solid basis for modern science. Elsewhere William Ashworth jr. observed the very same propensity for observation and experiment, at the expense of theory, among Catholic natural philosophers. Ashworth jr., however, saw this as a symptom of the scientific repression ensuing from the Galileo-affair. ${ }^{13}$ Here the preconceived model of Protestant progress versus Catholic stagnation conditioned the interpretation of what seems to be a similar methodological development on both sides of the confessional divide.

A corrolary to this persistent assessment of the devarication of Protestant and Catholic perspectives on the natural world in terms of progress and stagnation, is the assumed Protestant exaltation of nature as God's second book, as a source of divine revelation in its own right. According to this view, it was in the Protestant traditions that the investigation of natural phenomena, including human physiology and its pathologies, took on autonomous value as a way to honour the Creator. This view of naturalist knowledge supposedly dovetailed with the Protestant imperative to return to the Bible as the one and only textual source of divine revelation. Eric Jorink, in a seminal book on the study of nature in the Calvinist Dutch Republic, takes exactly such a view of confessional differentiation in this respect. He argues convincingly that religious motivations were at the heart of many natural investigations in the seventeenth century. He demonstrates the close affinity between biblical scholarship and natural studies, including medicine. But his work focusses on the Calvinists in the Dutch Republic, and attributes the devotional background of their natural studies to a specifically Protestant hermeneutics that looked for meaning in the details of both linguistic and natural knowledge. ${ }^{\mathrm{I}}$

It is thus easily assumed that the broad tradition of physica sacra, the study of natural phenomena featuring in Scripture, was mainly a product of Protestant

I3| William B. Ashworth Jr, "Catholicism and Early Modern Science", in David C. Lindberg and Ronald L. Numbers (ed.), God and Nature: Historical Essays on the Encounter between Christianity and Science, Berkeley, University of California Press, I986, p. I36-I66 (I52-I53); Carter Lindberg, "The Lutheran Tradition", in Ronald L. Numbers and Darrel W. Amundsen, Caring and Curing, Baltimore, Johns Hopkins University, p. I73-203 (I76-I83); James H. Smylie, “The Reformed Tradition”, in Caring and Curing, op. cit., p. 204-239 (2I4-2I5).

I4 | Pott, Säkularisierung in den Wissenschaften..., op. cit., p. 69-84; Eric Jorink, Het "Boeck der Natuere": Nederlandse geleerden en de wonderen van Gods Schepping, I575-I715, Leiden, Primavera Press, 2006, p. I3-I85. 
culture. In what follows, I will suggest that there is every reason to look in more detail at similar work having been done in the Catholic world, at least up until the second half of the seventeenth century.

The intellectual and cultural phenomenon of physica sacra has come to the attention of historians fairly recently. ${ }^{15}$ It brought knowledge of nature, more or less specialised, to bear on the literal reading of biblical passages. It should be distinguished from Mosaic physics, on one hand, which claimed that divine revelation, starting with the prophetic books of Moses, dictated the parameters of natural knowledge. It is also different from physico-theology, on the other, which sought, conversely, to do justice to the perfection of God as it emerged from the natural world. ${ }^{16}$ Whereas both Mosaic physics and physico-theology thus denote ways of appreciating natural knowledge, the term physica sacra focusses on interpretation of the biblical narrative. It enlisted existing expertise about the natural world for the explication of natural particulars occurring in the Bible. It both aided biblical study, by solving problematic episodes in Scripture, and ennobled natural study, by underscoring its utility in understanding the Word of God.

Here we examine that branch of physica sacra that dealt with functions of the body and the soul, disease, and healing, which we may loosely label medicina sacra, the application of medical knowledge to passages in the Bible. ${ }^{17}$ Bernd Roling has engaged with medicina sacra in his study of premodern exegesis of biblical wonders. He focussed on a biblical episode that for centuries raised questions about the ordinary workings of the human body and mind, and divine intervention: the temporary transformation of King Nebuchadnezzar into a savage, during which he grew long hair and claws, and ate grass like animals (Daniel 4). Commentators wondered about the extent to which the Babylonian king actually changed, whether it was a physical transformation or rather a psy-

I5 $\mid$ Kathleen M. Crowther, "Sacred Philosophy, Secular Theology: the Mosaic Physics of Levinus Lemnius (1505-1568) and Francisco Vallés (1524-1592)", in Jitse M. van der Meer and Scott Mandelbrote (ed.), Nature and Scripture in the Abrahamic Religions: Up to I7oo, II, Leiden, Brill, 2008, p. 397-428; Bernd Roling, Physica sacra: Wunder, Naturwissenschaft und historischer Schriftsinn zwischen Mittelalter und Früher Neuzeit, Leiden, Brill, 2013; Berns, The Bible and Natural Philosophy..., op. cit.

I6 Amos Funkenstein, Theology and the Scientific Imagination from the Middle Ages to the Seventeenth Century, Princeton, Princeton University Press, 1986; Ann Blair, "Mosaic Physics and the Search for a Pious Natural Philosophy in the Late Renaissance", Isis, 9I, 2000, p. 32-58. All concepts, physica sacra, physica mosaica and physico-theology, are modern constructs, appropriating terms used sporadically and unsystematically in premodern sources.

I7 | Again, we should distinguish this medicina sacra, which deals with medical questions arising from the text of the Bible, from the "medicina sacra", meaning medical therapy meted out by religious men and women, as discussed by Gianna Pomata, "Medicina delle monache. Pratiche terapeutiche nei monasteri femminili di Bologna in età moderna", in Gianna Pomata and Gabriella Zarri (ed.), I monasteri femminili come centri di cultura tra Rinascimento e Barocco, Roma, Edizioni di Storia e Letteratura, 2005, p. 33I-363 (331, 337-343). 
chological affection. The many commentaries that Roling cites show Catholic and Protestant exegetes indiscriminately citing each other, both in theology and medical writings. ${ }^{18}$ Besides well-known Protestant practitioners of medicina sacra such as Thomas Bartholin (I6I6-I680) and Richard Mead (I673-I754), we encounter several Catholic exponents from the late sixteenth to the mid seventeenth century: Francisco Valles (I524-I592), Vicente Moles (dates unknown), Marcelino Uberte ( $\left.{ }^{\mathrm{O}} \mathrm{I} 589\right)$, Girolamo Bardi ( $\left.{ }^{\mathrm{O}} \mathrm{I} 603\right)$, and Michel Baldit (dates unknown). ${ }^{19}$ In this essay we briefly zoom in on two of them, Valles and Bardi, and juxtapose them with two Protestant counterparts, Johannes de Mey (I6I7-I678), a Calvinist physician in the Dutch town of Middelburg, and the aforementioned Bartholin, member of a Danish dynasty of Lutheran medical doctors in Kopenhagen.

\section{Medicine distinct from theology}

An early example of medicina sacra, and an important model for later generations, was a work by the Spanish medical scholar and practitioner Francisco Valles. Valles was among the most prominent medical professionals in sixteenth-century Spain, rising to pre-eminence professionally, institutionally, and intellectually. He was a professor of medicine in Alcalá de Henares, then from 1572 personal physician to king Philip II (I527-I598) of Spain. He was also renowned as a humanist commentator, of Hippocrates, as well as Galen and Aristotle. ${ }^{20}$ Moreover, he became the protomédico of the Kingdom of Castilia in a period in which the Spanish crown was centralising control over medical practice. Under Philip II, university trained medical doctors were elevated to the top of a pyramid that included surgeons, apothecaries and midwives. The protomédico was instrumental in this process of centralisation. Valles himself was involved in the tightening of royal control of pharmaceutical services, at the expense of local interests. ${ }^{21}$ This testifies to Valles's eminent position within the medical profession in Spain.

I8 | Roling, Physica sacra, op. cit., p. 305-317.

I9| Francisco Valles, De iis quae scripta sunt physice in libris sacris, Lyon, Le Fèvre, I588; Vicente Moles, De morbis in Sacris Literis pathologia, Madrid, J. Sancius, I642; Girolamo Bardi, Medicus PoliticoCatholicus, Genua, G.M. Farroni, I643; Marcelino Uberte, Medicina sacra, Zaragoza, Typographia Generalis Regii Xenodochii Deiparae de Gratia, I645; Michel Baldit, Speculum sacro-medicum octogonum, Lyon, D. Gayet, [I666].

20| Ana Isabel Martín Ferreira, El humanismo médico en la Universidad de Alcalá (siglo XVI), Madrid, Universidad de Alcalá, I995, p. 58-64; Craig Martin, "Francisco Vallés and the Renaissance Reinterpretation of Aristotle's 'Meteorologica' IV as a Medical Text”, Early Science and Medicine, 7 , 2002, p. I-30 (I8-20).

2I | Michele L. Clouse, Medicine, Government, and Public Health in Philip II's Spain: Shared Interests, Competing Authorities, Burlington, Ashgate, 20II, p. 43-74, I27-I40. 
In 1587 Valles published De iis quae scripta sunt physice in libris sacris, sive de sacra philosophia. It was a collection of sacred texts, touching on questions of medicine, natural philosophy and science in general. In the preface, the author claimed that after having composed commentaries on the typical medical authorities, Aristotle, Hippocrates and Galen, at the end of his life he now turned to the Bible. ${ }^{22}$ But rather than the pious ruminations of a professional who felt the end of his life approaching, the publication may have been intended as a sanctification of learned medicine, in its leading role in the newly centralised medical regime of Philip II. A parallel ambition motivated for instance Juan Bautista Villalpando (1552-1608), Jesuit and architect of Philip II, to argue that the design of the biblical Temple of Solomon was identical with the architecture of the Escorial. ${ }^{23}$ Worldy knowledge, architectural theory as well as the medical arts, would reveal themselves to be indispensible in reconstructing sacred historyand enjoy authority accordingly.

In his book, Valles interpreted biblical passages in terms of medicine and natural philosophy, as well as highlighting the importance of medicine in the Bible. ${ }^{24}$ In fact, the author devoted almost a third of the text to medicine. Significantly, the verse cited above from the Book of Sirach (38:4) occasioned an extensive comment on the dignity of the medical profession. Valles suggested that the work of the physician and of the priest ran parallel. Where God had relegated to the priesthood the office of giving life to the human soul, the medical arts had the task of sustaining the life of the body. Priests and physicians worked in close collaboration. In the three-tier social hierarchy modelled on Plato's Republic (the wise, the warriors and the workers) Valles explicitly included medical practitioners in the ruling estate of the wise, ranking them right underneath the theologians - and above the lawyers. ${ }^{25} \mathrm{He}$ paraded the medical profession as a divinely instituted art.

Ann Blair characterized Valles as a proponent of Mosaic physics (as did several seventeenth- and eighteenth-century authors): having to the Bible to

$22 \mid$ Valles, De iis quae scripta sunt..., op. cit., p. 6-7.

23 | Jetze Touber, "Applying the Right Measure: Architecture and Philology in Biblical Scholarship in the Dutch Early Enlightenment", The Historical Journal, 58, 2015, p. 959-985 (963-965).

24 | Giancarlo Zanier, Medicina e filosofia tra '500 e '60o, Milan, FrancoAngeli, 1983, p. 20-38; Crowther, "Sacred Philosophy, Secular Theology", op. cit., p. 4I2-422. I have used the second edition: Franciscus Valles, De iis quae scripta sunt physice in libris sacris, sive de sacra philosophia, Lyon, Le Fèvre, I588.

$25 \mid$ Bernd Roling, "Der Bibel als Summe der Naturwissenschaften: Die 'Philosophia sacra' des Franciscus Vallesius", in Günter Frank and Stephan Meier-Oeser (ed.), Hermeneutik, Methodenlehre, Exegese: Zur Therie der Interpretation in der Frühen Neuzeit, Stuttgart-Bad Canstatt, frommannholzboog, 20II, p. 265-286 (277-278). On rivalry between medicine and law in the early modern period, cfr. Silvia De Renzi, "Medical Competence, Anatomy and the Polity in Seventeenth-Century Rome", in Sandra Cavallo and David Gentilcore (ed.), Spaces, Objects and Identities in Early Modern Italian Medicine, Oxford, Blackwell, 2008, p. 79-95 (86-89). 
determine the perimeters of what was sound knowledge about nature, including the workings of the human body. ${ }^{26}$ However, it is doubtful whether Valles was really so modest about his own profession. The Bible does not teach the subtle workings of nature, Valles says in the preface, referencing Ecclesiastes I. He does claim that if natural phenomena make their appearance in the biblical narrative, they must be very true, "since they were dictated, after all, by the truest spirit of God, and flow from the the author of nature itself, for whom nothing can remain hidden." ${ }^{27}$ But it was the art of the natural philosopher-or that of the medical doctor-that he employed to confirm that truth.

If we look more closely at how he actually commented biblical episodes, his message that the biblical exegete actually had something to learn from the medical doctor shimmers through. He set the example by applying his medical expertise to a range of diseases occurring in the Bible. One example is the case of king Hezekiah of the Jews (around 700 BCE), who developed a malignant ulcer. The prophet Isaiah predicted that the sore was to be fatal. When the king, in tears, implored God to cure him, God decided to spare the king and ordered Isaiah to inform him of the decision. At the prophet's command, Hezekiah's servants treated the king with figs, succesfully: "And Isaiah said, Take a lump of figs. And they took and laid it on the boil, and he recovered." 28

At first sight this biblical episode seemed to report God's direct intervention in a deadly disease. The application of the "lump of figs", however, opened up the possibility that the cure had really been effected by treatment with a fruit poultice. To determine what had been the case, Valles started out his comment with specifiying a succinct typology of miraculous cures. Healing miracles might result either from the utterance of plain words or prayer, or from the application of a material substance, like a normal medicine. Examples of the latter type included, besides the ulcer of Hezekiah, the gall of fish that cured the father of Tobias, and the river water in which the Aramese general Naaman had his skin cleansed of lepra. ${ }^{29}$ Valles observed:

But whether these things, applied to the bodies that were to be cured on God's orders, truthfully were medicaments, and endowed with a nature that destined them to cure diseases of themselves, or not, [...] is worthy of consideration, and the examination of this thing is up to the Physician..$^{30}$

26 | Blair, "Mosaic Physics...", op. cit., p. 36-37, 42-43.

27 | utpote quae, a summe vero Dei spiritu, dictata sint, \& ab ipso naturae autore fluxerint, quem latere nihil potuit. Valles, De iis quae scripta sunt..., op. cit., p. 5-6, quotation on p. 6.

$28 \mid 2$ Kings 20:I-7.

$29 \mid$ Valles, De iis quae scripta sunt..., op. cit., p. 316.

30 | Sed an haec quae Dei iussu sanandis corporibus admoventur, re vera sint medicamenta, eaque natura praedita, ut per sese nata sint eos morbos curare, an non, [...] dignum est consideratione, E spectat eius rei examen ad Physicum. Valles, De iis quae scripta sunt..., op. cit., p. 316. 
Valles thus claimed for himself, as a physician, the authority to determine whether the biblical cures were in accordance with the natural properties of the substances used, in the light of current medical knowledge. In effect his investigation would amount to a preliminary inquiry, elucidating the medical properties of the substances involved, for the competent theologians to draw their conclusions.

Did medical knowledge suggest that king Hezekiah had been cured in a natural way? A long-drawn-out discussion followed of the preparation of concoctions of figs, with their different therapeutical effects, and of types of ulcers, and a review of what exactly might have happened in Hezekiah's case. Quite possibly, the dangerous inflammation caused by the king's ulcer would have been remedied by the application of a poultice made from fig pulp and wheat or barley flour. That scenario would seem to have ruled out God's extraordinary intervention. ${ }^{31}$

In the end, Valles came round, reaffirming God's direct, glorious intervention. Even if figs would have effected a reversal of Hezekiah's life threatening situation, they would not have had the power to restore the king's strength sufficiently to allow him to go up to the Temple within three days. Clearly, God had enhanced the healing power of the poultice. Valles gleaned a moral significance from the course of events as narrated in the Bible, which underscores the concerted efficacy of medical art and the divine will:

This makes us see distinctly that it is not so much the powers of medication in which we should have faith, but the grace of God, which inspires those powers. (...) Hezekiah demonstrates, therefore, that even mediocre medicines can effect very much if aided by divine power. ${ }^{32}$

Divine power and the medical art collaborated. God willed that the efficacy of the medical substance exceeded that which it possessed normally-working directly through the medical art, without intercession of any spiritual authority.

After Valles's decease, his engagement with Scripture would be contested. The third edition, Lyon I592, was censured in the Spanish Index of I6I2, ordering the expurgation of nine passages. ${ }^{33}$ This expurgation awaits proper study, but it may have been that Valles (posthumously) rubbed the clerical censors the wrong

3I| Valles, De iis quae scripta sunt..., op. cit., p. 316-319.

32 | Unde facile constat non tam esse fidendum medicamentorum facultatibus, quam gratiae Dei, qui his ipsis aspiret. [...] Quod itaque medicamenta etiam mediocria favente numine plurimum possint, argumento est Ezechias, Ibid., p. 319.

33 | Index librorum prohibitorum et expurgatorum, ed. Bernardo Sandoval y Rojas, Madrid, Ludovicus Sanchez, I6I2, p. 342; see José Pardo Tomás, Ciencia y censura: la Inquisición española y los libros científicos en los siglos XVI y XVII, Madrid, Consejo Superior de Investigaciones Científicas, I99I, p. $25 \mathrm{I}-252$. 
way, in the manner in which he distributed responsibility for biblical interpretation between clergy and medicine. Commenting Genesis 6, on the "sons of God" who took the daughters of men for wives, Valles acknowledged that theologians might frown upon his analysis because of its pastoral implications, but that he was only concerned with natural issues: "Maybe theologians would say that God denies grace to the offspring of such vile acts. For me it suffices to express only what matters to nature." This passage was expurged. Again, in his commentary to the Book of Job, Valles states "as far as nature is concerned, the face of the Earth is truly eternal. [my emphasis]" This sentence was eliminated as well. ${ }^{34}$ It may have been this explicit juxtaposition of theology (the domain of the clergy) and natural knowledge (the preserve of the medical doctors), implying that medicine had independent autonomy, that was not condoned by the Spanish Inquisition.

\section{Medicine symbiotic with theology}

Half a century later, the Genoese physician Girolamo Bardi created a hybrid of theological and medical expertise, in his Medicus Politico-Catholicus (I643). Different from Valles, Bardi conflated the engagement with physical conditions and spiritual states, as proper to both the medical doctor and the clergy: "They carry a cure, not so much for the disease that needs to be combatted, but rather for the sin that must be destroyed root and branch, trained to fulfill the responsibilities of both priests and medical doctors." 35 The physician and the pastor merged, without the one being subservient to the other.

Bardi, who studied medicine and theology, had been affiliated with the Jesuit order for six years, but was honourably discharged. Subsequently (I633) he obtained a chair of philosophy in Pisa. In I635 he returned to his native region Liguria, where he published the Medicus Politico-Catholicus. In this book, he both explained physiological and pathological issues occurring in the Bible (digestion, ulcers, dropsy, blindness), and listed the medical activities of sacred figures such as Christ himself, his disciples, and certain saints. He showed himself open to intellectual novelties. He was critical of the aristotelianism prevailing in the universities, targeting among others his own teacher in Pisa, Rodrigues de Castro (ca. I559-ca. I637). He supported Galileo, endorsed the work of Marsilio Ficino

$34 \mid$ Theologi fortasse dixerint, denegasse Deum gratiam ex adeo nefandis criminibus natis. mihi satis sit dixisse quae ad Physicam spectant. and aeterna vero est naturaliter haec mundi facies. Valles, De iis quae scripta sunt..., op. cit., p. I27-I28, 348; Index librorum prohibitorum..., op. cit., p. 342.

$35 \mid$ Panaceam non tam ad morbos expugnandos secum ferunt, sed ad peccata extirpanda radicitus, in utrumque parati Sacerdotum functi officio, E Medicorum. Girolamo Bardi, Medicus Politico-Catholicus, Genua, G.M. Farroni, I643, p. 270. Cfr. Winfried Schleiner, Medical ethics in the Renaissance, Washington, Georgetown University Press, 1995, p. 94-99. 
and Tommaso Campanella, and was himself committed to iatrochemistry. ${ }^{36}$ But he also demonstrated his allegiance to the Counter-Reformation clergy by dedicating his Medicus Politico-Catholicus to the belligerent Archbishop of Genoa, Stefano Durazzo (I594-I667), who was locked in a bitter conflict over legal and fiscal rights with the civil government of the city. ${ }^{37}$

Wolfgang Eckhardt has understood Girolamo Bardi's work as an instance of early modern deontological medical literature. Bardi claimed that theology and medicine were closely related. The medical doctor, accordingly, needed to develop the qualities of a Catholic Christian, in imitation of Christ himself, the first physician. The virtues that, according to Bardi, distinguished the legitimate physician from a quack, were moral ones, first and foremost: justice (iustitia) and loving kindness (charitas), respectable customs (boni mores), chasteness (castiditas) and modesty (modestia). Beyond that, a physician also needed to be a good philosopher - a moral philosopher, to be precise..$^{8}$ Such an interpretation of Bardi's assessment of the qualities of a good physician, should be placed against the background of a developing confessional society, where various professional groups needed to secure their position in a divinely sanctioned social order.

Like Valles's work, the Medicus Politico-Catholicus purported to give evidence of the close connection between medicine and theology, suggesting even the sacred character of the medical art. It reads unmistakably as a celebration of medicine. Its chapters run from the "divine origin of medicine", through the medical operations of the prophets, to the medical art of Christ and saints. Bardi implied a more fluid relation between theological and medical perspectives on biblical history, than Valles did. He himself manoeuvred the fine line of biblical events that were neither completely supernatural, nor completely natural: "if it is considered natural as to its substance, but supernatural as to its mode [...] this will be a subject matter of our work" ${ }^{39}$

Furthermore, Bardi's medicina sacra reflects the pronounced position which he assumed in the medical debates of his time, being a strong supporter of iatrochemistry.40 Thus, when Bardi speculates on the reasons why Moses forbade the Jews to consume pork, he combines observations on dietary culture with

36 | Francesco Cagnetti, "Bardi, Girolamo", in Dizionario Biografico degli Italiani (DBI), VI, Rome, Treccani, I964, p. 303-305.

37 | Matteo Sanfilippo, "Durazzo, Stefano”, in DBI, XLII, I993, p. I78-I8I.

$38 \mid$ Wolfgang Eckhardt, “"Medicus Politicus” oder „Machiavellus Medicus”? Wechselwirkungen von Ideal und Realität des Arzttypus im I7. Jahrhundert”, Medizinhistorisches Journal, I9/3, I984, p. $210-224$ (220).

39 | si ut naturalis consideretur quo ad substantiam, E supernaturalis quo ad modum [...] nostri haec etiam erit operis argumentum, Bardi, Medicus Politico-Catholicus, op. cit., p. 2.

40| Cagnetti, "Bardi, Girolamo", op. cit.; for Italian iatrochemistry in these years see Giancarlo Zanier, "La medicina paracelsiana in Italia: aspetti di un'accoglienza particolare", Rivista di storia 
iatrochemical ideas concerning digestion. Again, at the end of the chapter on Hezekiah's ulcer the author added a brief "Corollarium" in which he gave an account of remedies against ulcers, explicity from a iatrochemical point of view. ${ }^{4 I}$ Bearing in mind the Hippocratic references in Valles's De iis quae scripta sunt physice, half a century earlier, we may appreciate how strongly biblical medicine was conditioned by topical debates in medical theory. Bardi, at least, seems to have been anxious not only to underscore the relevance of learned medicine to an understanding of Sacred Scripture in general, but to have attempted to advance iatrochemical medicine in particular.

As for the cure of Hezekiah, Bardi concurred with Valles that the progress of the king's disease displayed a combination of natural and supernatural elements: "it is evident that this recovery was in part supernatural, and in part natural". ${ }^{42}$ God could have chosen to heal the patient straight away, but he preferred to have the disease run its course for three days before recovery set in. Bardi agreed with Valles that the poultice of figs was a plausible remedy against the ulcer. Nevertheless, to consider the extraordinary speed with which the king regained his strength as a divine miracle, making God's intervention manifest, seemed implausible to Bardi. According to the Genoese physician, the real miracle was what followed immediately upon Isaiah's intervention: Hezekiah requested a sign which would proof that God would grant him I5 more years of life, upon which God made the shadow of the sun clock run backwards Io degrees (Isa. 38:5-8). Bardi then embarked on a discussion of how the reverse course of the shadow of the sun clock related to the celestial movements. ${ }^{43}$

Bardi thus shifted the locus of the miracle to another verse in the dense biblical text. The reversing shadow was a more convincing sign of divine intervention than the enhanced efficacy of the figs. This would be in accordance with the tendency of the Counter-Reformation church to demand that a healing was unambiguously inexplicable to accept it as a miracle ${ }^{44}$ - a requirement hardly met by a quick convalescence. But that may be reading too much into Bardi's different interpretation. In any case, on a more general level Valles's and Bardi's approach to medicina sacra overlapped. Both authors seem to have been concerned with demarcating a proper sphere of competency for the medical art, in conjunction

della filosofia, 40, I985, p. 627-653; Giorgio Cosmacini, Storia della medicina e della sanità in Italia, Rome, Laterza, $2005^{9}$ [1987], p. I57-I94.

4I | Bardi, Medicus Politico-Catholicus, op. cit., p. 4I-77, 94-96.

42 | clarè apparet, quod haec curatio fuerit partim supernaturalis, partimque etiam naturalis, Bardi, Medicus Politico-Catholicus, op. cit., p. 90.

$43 \mid$ Bardi, Medicus Politico-Catholicus, op. cit., p. 90-94.

44 | Fernando Vidal, "Miracles, science, and testimony in Post-Tridentine saint-making”, Science in Context, 20, 2007, p. 48I-508. 
with the clergy, but also on an equal footing. We will see how that worked out in medicina sacra ermerging from Protestant Europe.

\section{Medicine necessary for theology}

In the years after the publication of Bardi's Medicus Politico-Catholicus, Johannes de Mey, a Reformed minister in the Dutch Republic, published a spate of devout publications on nature. Like Bardi, De Mey had studied both theology and medicine, and although unlike Bardi he persisted in an ecclesiastical career, he was clearly engaged with the study of nature throughout his life. In I672, at the end of his life, De Mey received an appointment as a lector of physics in the Athenaeum Illustre of Middelburg, his native town. The government of Middelburg, like those of other Dutch urban centres in these years, was torn by the adherents of a strict ecclesiastical control over church discipline and biblical exegesis, and the advocates of a more individual engagement with piety and revelation. ${ }^{45} \mathrm{De}$ Mey tended towards the latter. ${ }^{46}$

De Mey's works celebrated God's omnipotence, as evinced by Creation. Huib Zuidervaart, one of the few historians to have studied De Mey, characterises his early publications as Mosaic physics, while Eric Jorink sees him as a transitional figure between Mosaic physics and physico-theology-gradually inverting the relative authority of Scripture and nature when it came to the interpretation of natural phenomena. ${ }^{47}$ Meanwhile we may consider his Sacra Physiologia (I655), a compendium of questions of natural philosophy and natural history raised by the biblical text, also as an instance of medicina sacra: applying learned medicine to the interpretation of events narrated in the Bible. Like Valles, De Mey ran through the text of the single Bible books, picking out verses and passages which occasioned reflection on a variety of themes. As in Valles's work, De Mey's discussion of medical, astronomical, physical and biological issues served to highlight the intimate relationship between human intellectual achievements and divine will. Yet, they differed in the precise nature of this relationship.

De Mey's discussion of the cure of king Hezekiah's ulcer may serve to illustrate this. Similar to Valles, De Mey concentrated on the properties of figs when applied to an excrescence. The minister drew on the same medical authorities (Galen, Dioscorides) for the suggestion that a mixture of figs ground together with wheat or barley flour would cause the tumescence to dry out, to soften,

$45 \mid$ Jonathan I. Israel, The Dutch Republic: Its Rise, Greatness, and Fall, I477-I806, Oxford, Clarendon Press, 1995, p. 758-766, 896-899.

46 | Huib Zuidervaart, "Het natuurbeeld van Johannes de Mey (I6I7-I678), hoogleraar filosofie aan de illustere school te Middelburg”, Archief [not numbered], 200I, p. I-40.

47 | Zuidervaart, "Het natuurbeeld...", op. cit., p. 7; Jorink, Het “Boeck der Natuere”, op. cit., p. 386-405. 
or to fester. Like Valles and Bardi, De Mey thought that these effects sufficed to make the king recover from his ulcer. From here onward, however, the Catholic physicians and the Dutch minister parted ways. De Mey refused to accept that a miracle had taken place. In his opinion, it might be true that God had decided that the king be liberated from his affliction, but he had chosen to avail himself of a natural remedy:

Even if it had been God's decree to liberate the king from this illness from which he suffered, yet he did not consider it at all necessary to do this in any other way than by a remedy which was consonant with nature $4^{88}$

Accordingly, De Mey drew a wholly different lesson from the episode of Hezekiah's cure than Valles and Bardi. The events showed, according to De Mey, that the prophet Isaiah had not only been knowledgeable about divine matters, but versed in human knowledge as well: medicine, physics. And Isaiah was not the only prophet to have been instructed in the sciences. Moses, Solomon and Daniel had also been engaged in natural studies. This should persuade theologians to follow their example and study nature themselves: "It is befitting to his example that the spirits of theologians are aroused to strive for knowledge." 49 Rather than appeal to the medical arts in deference to the unknowable contribution of God in each single case, De Mey encouraged his readers to trust fully in the capacities of human cognition, in acknowledgement of the approval of a benevolent God.

Zuidervaart presented De Mey as a "half-enlightened" naturalist, who admittedly held on to the authority of the Bible, but refused to read natural events such as meteors as signs of divine or diabolic intervention. As an argument in favour of De Mey's progressive position, Zuidervaart cites the minister's commitment to sustained observation of natural phenomena, in a Baconian vein-analogous to similar appraisals of Puritans and Lutherans, cited above..$^{50}$ The "disenchantment" implicit in this interpretation, does not, however, seem to do justice to De Mey's intense engagement with the Creator and Scripture. Rather than seeing a budding Enlightenment, in De Mey we may witness an ever deepening interpenetration of scriptural and natural revelation in the seventeenth century, in which philology and natural observation and experimentation were

48 Etsi decrevisset Deus morbo hoc quo laborabat, regem liberare: tamen id sibi nequaquam faciendum existimavit, sine remediis naturae consentaneis, Johannes de Mey, Sacra Physiologia, sive Expositio locorum Sacrae scripturae, In quibus agitur de rebus naturalibus, Middelburg, Fierensius, I655, with appended, with a separate title page: Commentariorum physicorum Pars 2. 3. et quarta, Middelburg, Fierensius, 1652, p. 40.

49 | Ejus exemplo par est excitari studiosorum etiam Theologorum animos ad cognoscendi studium., De Mey, Sacra Physiologia, op. cit., p. 40.

$50 \mid$ Zuidervaart, "Het natuurbeeld...”, op. cit., p. I7-2I. 
the means by which to disclose the knowledge contained in the Bible and in nature, respectively.

Here there may be a difference between the Catholics Valles and Bardi, on one hand, and the Reformed De Mey, on the other: whereas the former strove to validate the knowledge of the medical doctor side-by-side with the theologian, retaining a domain of biblial interpretation exclusive to the competency of the clergy, the latter exhorted the theologian himself to become a medical doctor (as well as a natural philosopher). Whereas Bardi still limited the scope of medical knowledge to what was "natural as to its substance, but supernatural as to its mode", leaving the truly supernatural to the theologians, De Mey articulated competency in all biblical matters relating to natural phenomena in terms proper to medical and natural knowledge.

\section{Medical prestige}

We end this brief survey with Thomas Bartholin, the renowned scholar and "indefatigable medical networker" from Lutheran Denmark. ${ }^{51}$ Bartholin was the son of Caspar Bartholin (I585-I629) and grandson of Thomas Fincke (I56II656), both eminent professors of medicine in Copenhagen, and founders of the dynasty that dominated university life in that city for a century. Thomas Bartholin published extensively, not only on anatomy and pharmacology, but on medicina sacra as well. His books include meditations on Christ's side wound, the crucifixion, and the paralytics whom Christ cured. ${ }^{2}$ After his library had burnt down in 1670, he published a brief "Medical Miscellany of Biblical Diseases" (De morbis biblicis miscellanea medica) in I672. According to the preface it "would have grown to a greater length if the thread of my writing had not been broken by other matters which were serious to me, rather than interesting to the public", probably in reference to the personal setback which had caused the loss of his books and manuscripts..$^{53}$

Similar to the other authors discussed so far, Bartholin devoted one chapter to the healing of king Hezekiah's ulcer. Bartholin ignored the work of Valles, crediting instead De Mey with determining the composition and therapeutical

5I| Gianna Pomata, "Sharing Cases: The Observationes in Early Modern Medicine", Early Science and Medicine, 15, 2010, p. 193-236 (225).

52 Ian Herbert Porter, "Thomas Bartholin (I6I6-80) and Niels Steensen (I638-86), Master and Pupil", Medical History, 7, 1963, p. 99-I25; Johan Schioldann-Nielsen and Kurt Sørensen, "Introduction", in Thomas Bartholin, On Diseases in the Bible: A Medical Miscellany, I672, transl. James A. Willis, Copenhagen, Danish National Library of Science and Medicine, 1994, p. 9-18.

53 | Singula in majorem molem excrevissent, nisi negotia alia interrupissent sermonis suscepti filum, graviora mihi quam publico, Thomas Bartholin, De morbis biblicis miscellanea medica, Frankfurt, D. Paullus, I672 [I672], sig. 3vo. 
efficacy of the poultice made of dried fig pulp ground together with flour. He also referenced Bardi, and he acknowledged that the cure prescribed by Isaiah was partly natural, partly supernatural. The convalescence of three days suggested a course of the disease in which natural effects and divine intervention collaborated. In other words, at least in this instance, there was certainly no simple trajectory of Catholic medical authors embracing a concerted involvement of God and nature in individual diseases, and Protestant authors privileging a natural explanation while relegating divine involvement to the remote background.

Significantly, though, Bartholin seems not to have been overly concerned with the extent to which biblical diseases and cures were miraculous. Different from Valles, Bardi and De Mey before him, Bartholin made little to no effort to establish in which way exactly the illness and the recovery of Hezekiah testified to God's omnipotence. Insofar as he elaborated the work of his predecessors, it was mainly to add pathological detail, displaying his mastery of the medical art. His own contribution to the interpretation of the ulcer of Hezekiah's was to give a more precise diagnosis:

I dare to assert that the underlying ailment was angina, which, because it is a very acute disease, uses to be fatal on the third day. ${ }^{54}$

Agreeing with Bardi that God had allowed to run the illness its natural course before effecting recovery, the Danish physician added that the king "had to be healed on the third day, which is critical in very acute diseases". ${ }^{5}$ If he referred to divine intervention, it was in general terms as God's decisions: "Hezekiah escaped by the hand of God", similar to the case, for instance, of the arthritis of the biblical king Aza (2 Chronicles I6): "when it finally killed the King, God allowing". ${ }^{6}$ The application of the medical art to determine the exact proportions of nature and divinity in the physical dynamics of recovery was beyond Bartholin's aims.

The showcasing of his own virtuoso medical knowledge and experience would seem to have been more important to Bartholin than establishing precisely the relationship between natural properties and divine intervention. This may be corroborated by his involvement with the debate over the so-called "unicorn horns" (actually narwhal teeth) that were part of natural collections across Europe, including the famous collection of Barholin's own uncle, Ole Worm (I588-I654). His uncle himself had cast doubt on the traditional identification

54 | Ego anginam subfuisse ausim affirmare, quae, quia peracutus morbus, tertio die perimere solet. Bartholin, De morbis biblicis..., op. cit., p. 47.

55 Ibid., p. 48.

56| Ezechias Dei manu evasit, dum tandem Regem occideret Dei permissione, Bartholin, De morbis biblicis..., op. cit., p. 47, 49. 
of these objects with the horns of the "unicorns", supposedly mentioned in the biblical books of Numbers, Deuteronomy and the Psalms. Bartholin appealed to a variety of disciplines (antiquarianism, comparative anatomy, material analysis), in order to prove his uncle right, and thus to guarantee the continued respect for his family as dominant members of Copenhagen's academic community. ${ }^{57}$ Similarly, in De morbis biblicis miscellanea medica, when discussing Aza's arthritis, Bartholin recounts the contrary opinions of both Bardi and his compatriot Sebastiano Baldo (dates unknown), calling them "friends", as to the nature of the affliction from which Aza suffered. Rather than deciding in favour of either of them, Bartholin paraded clinical observations of his own which could give support to either opinon:

Either one may be right. After all, I [have] known sufferers of gout who [were] consumed by the pain alone. I have seen others who succumbed to a transition of fluids to the major viscera, which caused a complication..$^{58}$

In a way, then, the Bible receded to the background of Bartholin's work on medicina sacra, in favour of his professional expertise. Significantly he left out a reflection on the relation between medicine and theology. Bartholin was first and foremost interested in whether his disquisitions were professionally sound.

\section{Reading Nature in Scripture: Baronio to Bartholin}

Soon after taking up a professorship of medicine in Copenhagen in I648, Bartholin produced a number of essays on the passion of Christ. In one of these he dealt extensively with the evangelical vinum myrrhatum, which Cesare Baronio had pondered half a century before..$^{59}$ Judging from the literature which Bartholin drew on, since the appearance of Baronio's Annales Ecclesiastici, the nature of the liquid offered to Christ had been extensively discussed by theologians and philologists as well as by natural historians and medical scholars. Bartholin was dismissive of Baronio's discussion: the cardinal had failed to distinguish between myrrha and murra, the former being bitter, the latter sweet. "All laugh

57| Bernd Roling, "Der Wal als Schauobjekt: Thomas Bartholin (I6I6-I680), die dänische Nation und das Ende der Einhörner With an English Summary”, in Karl A.E. Enenkel and Paul J. Smith (ed.), Zoology in Early Modern Culture: Intersections of Science, Theology, Philology, and Political and Religious Education, Leiden, Brill, 20I4, p. I72-I96.

$58 \mid$ Nam \& hic \& ille verus esse potest. Noti mihi podagrici solo dolore tandem consumti. Alios per metastasin humorum ad viscera nobilia, alio superveniente morbo, occubuisse observavi. Bartholin, De morbis biblicis..., op. cit., p. 49. On Sebastiano Baldo or Bado: Mario Crespi, "Bado, Sebastiano", in DBI, V, I963, p. 87-88.

59| Thomas Bartholin, De cruce Christi hypomnemata, Copenhagen, M. Martzan, I65I, p. I34-I59. 
at the fabrications of Baronio about the jars of murra", Bartholin observed. ${ }^{60}$ But it would be wrong to consider this simply a sneer of the naturalist Protestant physician Bartholin against the obscurantist Catholic prelate Baronio. Rather, several factors were in play that determined the appeal to natural knowledge in discussing biblical medicine.

The authors examined in this article constitute only a small sampling, and even then we have only had an impression of their works. Nevertheless they suggest that medicina sacra potentially opens up a wide range of approaches to the relation between learned medicine and biblical exegesis. The appeal to natural history by Baronio had served the aims of his project: parading the evidence for the immutability of the Church of Rome as the superior ecclesiastical institute. The physician Mercati duly procured a substance that corroborated the account which conformed to Baronio's theological and ecclesiological needs. But such a servile application of medical expertise to biblical interpretation was far from the only mode in which medicina sacra was practised. It would seem that Valles, Bardi and De Mey, alike, attributed a more autonomous role to the medical profession in biblical exegesis-albeit in different ways.

Valles detached the competence of the physician from the theologian, emphatically limiting his competence to the natural aspects of disease occurring in the Bible. Bardi seems to have envisioned a more blurred relation between medical and theological experts, both somehow engaged in questions of physical and spiritual health. Nevertheless, Bardi's celebration of medicine was tempered by caution when it came to the judgment of the truly miraculous. Again, De Mey took another approach still, advocating competence in natural knowledge-including medicine-as appropriate for the clerical experts entrusted with biblical interpretation, themselves. It may be tempting to attribute De Mey's refusal to judge Hezekiah's cure as a supernatural event to a more rationalist, autonomous perspective on medicina sacra than his Catholic predecessors held. However, his invitation to theologians fully to embrace worldly expertise such as medicine, may also be seen as a call to broaden the competency of theologians, rather than liberate medicine from obscurantist theology. Moreover, in Bartholin we have seen a Protestant scholar famous for his progressive intellectual position, accept the divine miracle in Hezekiah's case, after all.

The example of Bartholin shows another aspect that emerges in this brief survey: medicina sacra was subject to the internal dynamics of the medical profession, as well. In his discussion of biblical diseases, Bartholin seems to have been motivated by an opportunity of showcasing his observations as a medical practitioner. In this way he added to the professional prestige of himself and his

6o Bartholin, De cruce Christi hypomnemata, op. cit., p. I46, I49. 
family, much as he did in the reinterpretation of the narwhal teeth. Bardi, also, was obviously concerned to promote his iatrochemistry, possibly aspiring to ennoble that branch of learned medicine by showing its applicability in biblical interpretation. Similarly, we may see Valles as sanctifying the humanist medicine that gained in prominence in the decades in which he worked at the heart of the Spanish medical regime.

A more thorough investigation of the evolution of the genre of medicina sacra would be helpful to pinpoint turning points, and the extent to which rivalling opinions enjoyed broader support. The sample which we have examined, only begins to scratch the surface of what promises to be a rewarding field of study in the history of the relation of medicine and theology. 